\title{
Merek Terkenal \\ Menurut TRIPS Agréèment \\ dan Penerapan dalam \\ Sistem Merek Indonesia
}

Insan Budi Maulana

\begin{abstract}
The matter of legal protection to the well-known trademark holder is not only viewed from its legal aspects, but also from another facet, such as social and economy aspects in the society. These views should also be applied to the protection of the trademark in Indonesia. How is the real well-own trademark protection based on the TRIPS Agreements? And what is the relationship of application to the trademark system in Indonesia? This article will discuss these questions.
\end{abstract}

\section{Pendahuluan}

Persoalàn perlindungan hukum terhadap pemilik merek terkenal tidak hanya dapat dipandang dari aspek hukum saja; tetapi perlu pula dipandang dari aspek lain, misalnya dari aspek ekonomi dan sosial yang terdapat pada masyarakat itu. Dilihat dari aspek ekonomi dản sosial, termasuk pula faktor' yang mengakibatkan terjadinya sengketa "merek terkenal, "di antaranya; Pertama, kemampuan bersaing pemilik merek terkenal dengan beberapa pengusaha lokal atau "mereka" yang dianggap melakukan pelanggaran terhadap pemilik merek terkenal (asing) terjadi karena terdapat faktor-faktor yang tidak seimbang: Ketidakseimbangan itu terjadi karena kemampuan modal (sehingga dapat mendaftarkan merek-mereknya di berbàgái negara), dan súmber daya mañusiä yang meliputi pula kemampuan untuk melakưkan promosi, pemasaran ${ }^{1}$ serta persaingan yang jujur;

'Ukuran atau derajat keterkenalan suatu merek hendaknya jangan hanya digantungkan padà promosi yang gencar, didaftarkan di mancanegara saja tetapi.juga harus didukung pada pènggunaán yang nyatà. Jika mengklaim sebagai merek terkenal di Indonesia maka perlu pula didukung penggunaan yang nyata di Indonesia. Sikap ini dilakukan oleh RRC dalam kasus Kenwood vs. Sherwood. Juga pemahaman dan pengetahuan masyarakat atas merek tersebut, digunakan dan dimiliki oleh siapa. 
Kedua, hubungan kerjasama yang tidak seimbang atau jujur antara pemilik merek terkenal dan pengusaha lokal atau sebaliknya. Misalnya: perjanjian keagenan, distribusi, dan sebagainya sehingga terjadi "pemanfaatan" merek terkenal oleh segelintir pengusaha lokal. Pernah terjadi distributor lokal yang telah membangun jaringan distribusi dalam waktu yang cukup lama dengan biaya yang besar, ternyata hubungan distribusi itu dihentikan secara mendadak dan memilih distributor lain yang dapat memberikan keuntungan yang lebih besar. Atau, kepercayaan pemilik merek terkenal dikhianati oleh pengusaha lokal dengan cara mendaftar merek itu lebih dulu dibandingkan pemilik merek terkenal yang sebenarnya; ${ }^{2}$

Ketiga, karena sikap masyarakat yang kerapkali memilih "jalan pintas" dalam memenangkan persaingan, menunggangi hak-hak pihak lain, atau ketika memilih produkproduk asing yang disukainya. Rasa tidak percaya diri terhadap produk dalam negeri juga menjadi salah satu alasan kenapa masalah merek terkenal terjadi.

\section{Perundang-Undangan Nasional dan Internasional tentang Merek Undang-Undang No. 21 Tahun 1961}

Selain faktor-faktor ekonomi dan sosial tersebut di atas, faktor lain yang menjadi salah satu alasan mengapa sengketa merek terkenal (asing) terjadi di Indonesia adalah karena sistem hukum itu sendiri.

Selama UU di atas diterapkan, telah cukup banyak merek-merek terkenal (asing) yang didaftar lebih dúlu oleh para pendaftar merek yang bukan pemilik sebenarnya. Baik yang dilakukan oleh para pengusaha lokal —dalam hal ini para pengusaha keturunan Cina yang memiliki sense of business yang baik - dan juga oleh para pengusaha asing, misalnya; pengusaha Singapura, Hongkong, dan Brazil. Meskipun UU menyatakan bahwa pendaftaran merek hanya merupakan anggapan adanya hak, dan hak itu didasarkan pada penggunaan pertama karena pada saat itu Indonesia menerapkan first to use system, ${ }^{3}$ namun dalam realita di Pengadilan tidak sedikit pemilik merek terkenal (asing) kandas karena: 1) dianggap sebagai pemakai pertama; 2) masa mengajukan gugatan pembatalan telah kadaluwarsa; 3) pandangan legalistis sebagian hakim; dan 4) faktor-faktor eksternal lainnya; 4

Tetapi terdapat pula pemilik merek terkenal asing yang sukses mempertahankan hakhaknya, di antaranya, karena: 1) faktor adanya iktikad buruk dari pendaftar beritikad tidak baik yang menjadi dasar bagi hakim untuk membatalkan pendaftaran merek-merek terkenal asing (meskipun berbeda kelas dan .jenis barang); 2) pandangan hakim yang tidak

${ }^{2}$ Kasus-kasus seperti ini kerapkali terjadi karena faktor "ketidakadilan" semata yarig dilakukan oleh dan antara pemilik merek asing dengan pengusaha lokal.

${ }^{3}$ Pada saat ini hanyaAmerika Serikat saja yang masih menerapkan sistem ini. Sistem ini tentu saja dianggap lebih menguntungkan negaraitu.

${ }^{4} \mathrm{Hakim}$ Agung Indroharto dianggap hakim yang legalistis dan berbeda pandangan dengan Prof Asikin Kusumah Atmadja. 
menekankan faktor hukum saja tetapi juga faktor moral dan keadilan, serta kejujuran dalam melaksanakan persaingan, dan; 3) faktorfaktor eksternal, misalnya: politis. ${ }^{5}$

Pada saat ini, meskipun Indonesia telah mengakui Konvensi Paris melalui Keputusan Presiden (Keppres) No. 24 Tahun 1979 namun telah mengesampingkan Pasal 1 sampai dengan Pasal 20 konvensi tersebut. Berarti, Pasal 6 bis Konvensi Paris dikesampingkan dari pengakuan tersebut. Dalam praktik di pengadilan terdapat beberapa putusan yang mengakui pasal tersebut dengan mengacu pada Konvensi Paris yang diakui oleh Pemerintah Belanda dan diterima Indonesia berdasarkan Pasal II Aturan Peralihan UUD'45.

Sengketa merek terkenal asing pada kurun waktu itu mencapai puncak ketika Menteri Kehakiman mengeluarkan SK Menkeh 87 yang kemudian direvisi menjadi SK Menkeh 91 yang memberikan kewenangan bagi pemilik merek terkenal asing untuk mengajukan gugatan pembatalan, dan juga kewenangan bagi Kantor Merek untuk menolak atau membatalkan permintaan perpanjangan merek terkenal asing yang diajukan oleh pemohon yang tidak berhak. Sengketa merek terkenal ini mulai mengalami penurunan sejak UU No. 19 Tahun 1992 diberlakukan pada bulan April 1993.?

\section{Undang-Undang No. 19 Tahun 1992}

Perbedaan yang cukup mendasar antara UU No. 21 Tahun1961 dengan UU No. 19 Tahun 1992 adalah penerapan first to file system dalam UU ini. Artinya, hak atas merek diberikan kepada pendaftar pertama walau terdapat pengecualian yaitu: pendaftaran merek tetap harus dilakukan dengan itikad baik. Di dalam UU ini juga dicantumkan ketentuan yang memberikan perlindungan terhadap merek terkenal. Pasal 6 ayat (2) huruf a menyatakan: Permintaan pendaftaran merek juga ditolak oleh Kantor Merek apabila merupakan atau menyerupai nama orang terkenal, photo, merek dan nama badan hukum yang dimiliki orang lain yang sudah terkenal, kecuali atas persetujuan tertulis dari yang berhak. Dan penjelasan pasal tersebut menyatakan: Penentuan suatu merek atau nama terkenal, dilakukan dengan memperhatikan pengetahuan umum masyarakat mengenai merek atau nama tersebut di bidang usaha yang bersangkutan.

Dalam UU ini memang tidak dicantumkan definisi atau kriteria merek terkenal, namun dengan memperhatikan penjelasan pasal tersebut, sebenamya telah cukup memadai. Penjelasan merek terkenal itu bagi Indonesia -yang merupakan negara berkembang dan kebanyakan para pengusahanya belum

\footnotetext{
${ }^{5}$ Misalnya dalam kasus Pierre Cardin yang sempat datang ke Jakarta dan menemui keluarga Pṛesiden Soeharto dan mengeluhkan pelanggaran merek yang dialaminya.

'Lihat putusan-putusan perkara merek yang susunan majelis hakimnya diketuai oleh Prof. Asikin Kusumahatmadja șelama beliau menjadi HakimAgung.

'Lihat lebih lanjut dalam Insan Budi Maulana. 1999. Perlindungan Merek Terkenal di Indonesia dari Masa Ke masa. Bandung: CitraAditya.
} 
menyadari akan makna UU Merek - cukup memadai dan dapat mengakomodasikan kepentingan pengusaha kecil dan menengah nasional karena terhadap merèka tidak dibebankan harus melakukan promosi besarbesaran atau mendaftarkan mereknya di manca negára.

\section{Pasal 6 Bis Konvensi Paris dan TRIPS Agreement}

Perlindungan terhadap merek terkenal merupakan konsekuensi pengakuan Indonesia terhadap Agreement on Trade Related Aspects of Intellectual Property Rigths atau TRIPS Agreement yang tidak dapat dipisahkan dengan pengakuan Indonesia terhadap Organisasi Perdagangan Dunia atau WTO melalui UU No. 7 Tahun 1994. Ketentuanketentuan mengenai merek diatur dalam $P$ art II, Section II dari Article 15 sampai dengan Article 21. Dan ketentuan yang memberi perlindungan terhadap well-known trademark diatur dalam Pasal 16 ayat (2) dan ayat (3). Dalam Pasal 16 ayat (2) dinyatakan:

Article 6 bis of the Paris Convention (1967) shall apply, mutatis mutandis, to services. In determining whether a trademark is well known, Members shall take account of the knowledge of the trademark in relevant sector of the public, including knowledge in the Member concerned which has been obtained as a result of the promotion of the trademark (garis bawah penulis).
Pasal 16 ayat (3) menyatakan:

Article 6bis of the Paris Convention (1967) shall apply, mutatis mutandis, to goods or services which are not similar to those in respect of which a trademark is registered, provided that use of that trademark in relation to those goods or senvices would indicate a connection between those goods or services and the owner of the registered trademark and provided that the interests of the owner of the registered trademark are likely to be damaged by such use.

Jika memperhatikan ketentuan di atas terdapat beberapa hal utama dalam menentukan suatu merek menjadi well-known ${ }^{8}$ yaitu:

1. pengetahuan masyarakat yang relevan terhadap merek tersebut;

2. pengetahuan masyarakat terhadap promosi merek tersebut;

3. perlindungan terhadap merek terdaftar (terkenal) diberikan pula terhadap barang atau jasa yang tidak serupa (baca: tidak sejenis) apabila dapat menimbulkan kesan memiliki hubungan dan pemilik merek terdaftar itu dirugikan atas penggunaannya.

Sementara itu, Pasal 6 bis Konvensi Paris menyatakan:

(1) The countries of the Union undertake, ex officio if their legislation so permits,

${ }^{8}$ Penulis belum dapat menyatakan sebagai merek terkenal untuk istilah well known trademark terhadap interpretasi pasal di atas. 
or at the request of an interested party, to refuse or to cancel the registration, and to prohibit the use, of a trademark which constitutes a reproduction, an imitation, or a transiation, liable to creI ate confusion, of a mark considered by the competent authority of the country of registration or use to be well known in that country as being already the mark of a person entitled to the benefits of this Convention and used for identical or similar goods. These provisions shall also apply when the essential part of the mark constitutes a reproduction of any such well-known mark or an imitation liable to create confusion therewith;

(2) A period of at least five years from the date of registration shall be allowed for requesting the cancellation of such a mark. The countries of the Union may provide for a period within which the prohibition of use must be requested;

(3) No time limit shall be fixed for requesting the cancellation or the prohibition of the use of marks registered or used in bad faith.

Beberapa hal yang patut diperhatikan dari Pasal 6 bis Konvensi Paris yaitu:

1. Tidak mengatur definisi dan kriteria merek terkenal;

2. Penolakan, atau pembatalan pendaftaran merek, atau larangan penggunaan merek yang merupakan reproduksi, tiruan atau terjemahan yang dapat menyesatkan atas suatu barang atau jasa yang sama/serupa apabila perundang-undangan negara tersebut mengatumya atau atas permintaan suatu pihak yang berkepentingan;
3. Gugatan pembatalan dapat diajukan sekurang-kurangnya 5 (lima) tahun dari tanggal pendaftaran, namun tidak ada jangka waktu apabila pendaftaran itu dilakukan dengan iktikad buruk.

Dengan memperhatikan ketentuanketentuan yang diatur dalam TRIPS Agreement, dan mengacu pula pada Pasal 6 bis Konvensi Paris, suatu negara yang turut serta dalam persetujuan di atas berhak mengatur perlindungan merek terkenal di negaranya sendiri.

\section{Undang-Undang No. 14 Tahun 1997}

Ketentuan-ketentuan yang terdapat dalam TRIPS Agreement dan Pasal 6 bis Konvensi Paris, sekali lagi, merupakan ketentuan dasar yang seharusnya menjadi acuan bagi Indonesia dalam memberikan perlindungan terhadap merek terkenal. Jika memperhatikan UU No. 14 Tahun 1997 maka dapat dipetik beberapa pasal yang menunjukan bahwa Indonesia memberikan pertindungan terhadap merek terkenal (asing). Ketentuan tersebut di atas, yaitu:

\section{Pasal 6 ayat (2) huruf a yang} menyatakan:

Permintaan pendaftaran merek juga harus ditolak oleh Kantor Merek apabila: a) Menupakan atau menyenupai nama orang terkenal, photo, dan nama badan hukum yang dimiliki orang lain, kecuali atas persetujuan tertulis dari yang berhak;

2. Pasal 6 ayat (3) menyatakan:

Kantor Merek dapat menolak permintaan pendaftaran merek yang mempunyai persamaan pada 
pokoknya atau keseluruhannya dengan merek yang sudah terkenal milik orang lain untuk barang dan atau jasa yang sejenis, ${ }^{9}$ dan

3. Pasal 6 ayat (4) menyatakan: Ketentuan sebagaimana dimaksud dalam ayat (3) dapat pula diberlakukan terhadap barang dan atau jasa yang tidak sejenis sepanjang memenuhi persyaratan tertentu yang akan ditetapkan lebih lanjut dengan Peraturan Pemerintah.

Kemudian, penjelasan pasal tersebut di atas, menyatakan:

Ayat (2) huruf a: Penentuan suatu merek atau nama terkenal dilakukan dengan memperhatikan pengetahuan umum masyarakat mengenai merek atau nama tersebut di bidang usaha vang bersangkutan (garis bawah penulis).

Sedangkan penjelasan ayat (3) menyatakan:

Adapun mengenai kriteria merek terkenal, selain memperhatikan pengetahuan umum masyarakat, penentuannya juga didasarkan pada reputasi merek yang bersangkutan yang diperoleh karena promosi yang dilakukan oleh pemiliknya yạng disertai dengan bukti pendaftaran merek tersebut di beberapa negara (jika ada). Apabila hal-hal di atas belum dianggap cukup, maka hakim dapat memerintahkan lembaga yang bersifat mandiri (independent) untuk melakukan survey guna memperoleh kesimpulan mengenai terkenal atau tidaknya merek yang bersangkutan.

Mencermati ketentuan di atas dan membandingkan dengan ketentuanketentuan yang terdapat pada Konvensi Paris dan TRIPS Agreement dapat disimpulkan:1) ketentuan hukum tentang perlindungan merek terkenal di Indonesia tidak bertentangan dengan yang diatur dalam Konvensi Paris maupun TRIPS Agreement yang merupakan standar minimal bagi negara yang menjadi anggota WTO; 2) penolakan pendaftaran tidak dibatasi dalam "barang yang sejenis dalam satu kelas" saja ${ }^{10}$ tetapi juga dapat melampaui kelas barang yang berbeda tetapi masih termasuk dalam jenis barang yang serupa, ${ }^{11}$ misalnya: sepatu kulit (kelas barang 25) dengan tas kulit (kelas barang 18); 3) penolakan yang

'Bandingkan, misalnya, dengan pasal 4 ayat (1) angka (vi), (viii), dan (x) UU Merek Jepang No. 51 Tahun ' 1998 tentang merek yang tidak dapat didaftarkan apabila sama atau serupa dengan famous, atau well-known trademark. Dalam pasal itu terdapat istilah famous dan well-known. Juga lihat Pasal 56 UU Merek Tahun 1994 tentang perlindungan merek terkenal di Inggris yang menyatakan: (1) References in this Act to a trademark which is entitled to protection under the Paris Convention as a well known trademark are to a mark which is wellknown in the United Kingdom as being the mark of a person who - (a) is a national of a Convention country, or (b) is domiciled in, or has a real and effective ind ustrial or commercial establishment in, a Convention country, whether or not that person camies on business, or has any goodwill, in the United Kingdom.

${ }^{10}$ Lihat Pasal 6 ayat (1) UU Merek No. 19 Tahun 1992

${ }^{11 P e m e r i k s a a n ~ m e r e k ~ d i ~ A u s t r a l i a n ~ P a t e n t ~ O f f i c e ~ m e n c a k u p ~ p u l a ~ j e n i s ~ b a r a n g ~ y a n g ~ b e r a d a ~ d i ~ l u a r ~ k e l a s ~}$ atau jenis barang yang diajukan. Informasi diperoleh dari pemeriksa merek ketikamelakukan studi banding pada Juli 1999 bersama dengan Direktur Merek dan Direktur Hak Cipta pada saat itu. 
bersifat wajib dilakukan oleh Kantor Merek terhadap nnama oráng terkenal, photo, dan nama badan hukum yang dimiliki orang lain dan penolakan itu -menurut hemat penulistidak hanya terbatas pada barang dan atau jasa sejenis saja tetapi juga dapat mencakup kelas barang atau jasa lainnya, misainya: merek IWWAN TIRTA atau PIERRE CARDIN, atau BILL CLINTON tidak dibatasi pada jenis barang tertentu saja tetapi mencakup seluruh kelas barang dan jasa; 4) penolakan yang tercantum pada Pasal 6 ayat (3) bersifat tidak bersifat imperatif karena menyatakan "Kantor Merek dapat menolak permintaan pendaftaran merek yang sama atau serupa dengan merek yang sudah terkenal milik orang lain." Isi pasal itu agak "aneh" karena tidak mengharuskan terjadi penolakan. Kata 'dapat' di atas selayaknya menjadi 'harus' terutama apabila merek itu memang telah memenuhi persyaratan yang terdapat dalam penjelasan pasal tersebut. Jika pemahaman Kantor Merek terhadap pasal itu lebih dominan bersifat "dapat" maka akan mengurangi efektivitas penegakan hukum terhadap pemilik merek terkenal sebenamya. 5) ketentuan Pasal 6 ayat (4) ini yang menyatakan bahwa perlindungan terhadap merek terkenal dapat diberlakukan pula terhadap barang atau jasa yang tidak sejenis namun akan ditetapkan lebih lanjut dengan Peraturan Pemerintah, sebenarnya "agak mengganggu" dan dapat menimbulkan penafsiran beragam. Padahal -dalam beberapa hal- perlindungan hukum terhadap merek terkenal diluar jenis dan atau kelas barang yang berbeda.juga diperlukan, misalnya: merek COCACOLA yang penyebaran penjualannya telah masuk ke pelosok-pelosok, desa di tanah air. Walaupun merek itu digunakan untuk minuman namun patut dilindungi pula untuk kelas dan jenis barang yang lain; Faktor lain karena sistem merek di Indonesia tidak menerapkan sistem merek defensif, atau karena belum memiliki UU Anti persaingan Curang, misalnya: kasus COLA CANDY dengan kemasan berwarna merah. Walau Indonesia memiliki pasal $1365 \mathrm{KUH}$ Perdata yang dapat digunakan untuk mengatasi adanya praktik persaingan curang, namun masih banyak para praktisi hukum, seperti hakim, jaksa, dan pengacara termasuk subdit hukum Kantor Merek yang belum mau mengaitkan dengan UU Merek. Padahal inti dari pelanggaran $\mathrm{HaKI}$, khususnya pelanggaran merek berdasarkan pada adanya praktik persaingan curang. Sesungguhnya antara kasus merek dengan persaingan curang (ex Pasal 1365 KUH Perdata tentang perbuatan melanggar hukum) bagi dua sisi mata uang yang sepatutnya tidak dapat dipisahkan.

Dengan pertimbangan di atas, selayaknya Pasal 6 ayat (4) patut dipertimbangkan untuk dihapus saja dan kata "dapat" yang tercantum pada Pasal 6 ayat (3) selayaknya diganti menjadi kata "harus," agar tidak terjadi keraguan bagi Kantor Merek untuk menolak setiap permintaan pendaftaran yang memang sama atau serupa dengan merek yang sudah terkenal.

\section{Pelaksanaan Perlindungan Merek Terkenal di Luar Negeri}

Di bawah ini akan diuraikan beberapa kasus merek terkenal yang terjadi di luar negeri, misalnya: kasus merek Benz di India ${ }^{12}$

\footnotetext{
12Lihat IIC No. 3 Tạun 1995. HIm. 415 dstnya.
} 
yang merupakan masalah dilution of famous trademark antara Benz Jerman melawan Hybo Hindustan. Dalam kasus ini perusahaan lokal menggunakan merek "Benz dan logo tiga bintang dalam lingkaran" untuk pakaian dalam. Merek Benz Jerman telah didaftar di India sejak tahun 1951, dan akhirnya perusahaan tersebut memenangkan gugatannya. Sedangkan dalam kasus merek "Walkman" di Jepang perusahaan SONY Kabushiki Kaisha ${ }^{13}$ berhasil memenangkan gugatan terhadap toko sepatu yang menggunakan merek Walkman dengan logo "orang bersepatu sedang melangkah." Jika kasus ini terjadi di Indonesia kemungkinan SONY akan gagal karena kata "walkman" merupakan "generic name" yang mengacu pada taperecorder mini.

Kasus-kasus merek terkenal bukanlah "monopoli" Indonesia saja tetapi juga terjadi di luar negeri, termasuk di Pakistan, misalnya kasus merek Toshiba, dan negara-negara maju lainnya, seperti, Jepang, misalnya: kasus merek "CHANEL 5" untuk parfum terkenal yang didaftar untuk motel.

\section{Definisi Merek Terkenal}

Sampai saat ini tak ada seorang pakar pun yang mampu mendefinisikan merek terkenal. Yang dapat dilakukan adalah menentukan kriteria, dan ciri-ciri merek terkenal. Penentuan kriteria dan ciri-ciri merek terkenal itu juga didasarkan pada kepentingan nasionalnya masing-masing. Jika kemampuan perdagangan dan industri negara itu kuat maka kriteria dan ciri-cirinya dipilih yang akan menguntungkan negara tersebut. Sekarang ini yang menjadi keinginan negara-negara industri maju menginginkan kriteria dan ciriciri merek terkenal, misalnya; merek itu telah didaftarkan di berbagai negara, dan telah dipromosikan dengan gencar tetapi tidak mensyaratkan harus digunakan atau belum didaftar di negara tertentu, umpamanya: Indonesia. Padahal, umpamanya, pengusaha lokal di Indonesia telah menggunakan dan mendaftarkan merek itu sejak puluhan tahun yang silam, serta bentuk merek itu tidak sama tetapi bunyinya serupa. Jika persyaratan di atas - pendaftaran dan promosi yang gencaryang menjadi kriteria maka para pengusaha nasional yang kecil dan menengah tidak akan pernah bisa menjadi atau disebut sebagai pemilik merek terkenal. Yang akan memetik keuntungan hanyalah perusahaan-perusahaan besar saja.

Istilah apakah yang tepat terhadap kata "merek terkenal?"4 Apakah istilah itu disebut "merek yang sudah terkenal " ataukah disebut saja "merek terkenal" ataukah disebut "merek yang sangat terkenal." Juga perlu ditelaah istilah "merek yang sudah terkenal" ini apakah berasal dari padanan kata "well-known trademark" ataukah "famous mark ?" Karena kedua kata di atas terdapat sifat keterkenalan yang tidak sama. Ada yang berpendapat bahwa kata

\footnotetext{
${ }^{13}$ nformasi disampaikan dalam pelatihan HAKI pada bulan Juli 1997 yang diselenggarakan oleh JIII di Tokyo.

${ }^{14}$ Lihat pasal 6 ayat (3) UU Merek No. 14 Tahun 1997.
} 
"famous mark" $" 15$ lebih tinggi keterkenalannya dibandingkan dengan "well-known trademark." Jika diterjemahkan secara harfiah maka "wellknown trademark" disebut sebagai "merek yang dikenal baik, " sedangkan "famous mark" dianggap sebagai merek yang termashur.

Beberapa penulis asing membedakan istilah "well-known trademark" dengan "renown mark" dan juga dengan "famous trademark" bahkan istilah itu dibedakan pula pengkategoriannya berdasarkan kualitas dan kuantitas. ${ }^{16}$ Kemudian, pengadilan di Jerman ${ }^{17}$ menentukan kriteria merek itu famous apabila hasil survey menunjukan $80 \%$ responden mengenalnya dan dianggap merek itu wellknown apabila survey menunjukkan $40 \%$ responden cukup mengenalnya.

\section{Keterkaitan dengan Unfair Competition}

Sesungguhnya, sengketa merek terkenal tidak bisa semata-mata berdasarkan ketentuan yang diatur dalam UU Merek saja tetapi juga berkaitan erat dengan sengketa perbuatan melanggar hukum yang diatur dalam Pasal 1365 KUH Perdata, atau berkaitan dengan persaingan curang yang diatur dalam Pasal 382 bis KUH Pidana. Di negara lain, masalah sengketa merek kerapkali berkaitan erat pula dengan masalah persaingan curang, misainya: Jepang selain memiliki UU Merek juga memiliki UU Anti Persaingan Curang.

\section{Simpulan}

Ketidakteguhan perlindungan terhadap merek terkenal yang terjadi pada periode UU No. 21 Tahun 1961 selain karena sistem hukum yang lemah juga karena begitu banyak celah yang telah dimanfaatkan tidak hanya oleh para pengusaha yang ingin mendaftarkan merek terkenal dengan iktikad buruk, tetapi juga oleh aparat Kantor Merek, dan para praktisi hukum yang mencakup para kuasa hukum merek, dan hakim yang lebih mengutamakan kepentingan pribadinya semata. Meskipun sulit dibuktikan, tetapi "aroma" yang timbul dapat ditelaah, terutama, dari hasil keputusan badan peradilan baik yang memenangkan pengusaha lokal maupun asing.

Penyimpangan yang terjadi di saat sistem hukum merek baru atau menurut UU Merek No. 19 Tahun 1992 maupun UU Merek No. 14 Tahun 1997, di antaranya, yaitu:

(a) karena sarana dan prasarana -termasuk tingkat kesejahteraan-yang disediakan Pemerintah terhadap aparat Kantor Merek tidak memadai, di samping karena faktor penerimaan masuk dan pengolahan sumber daya manusia yang kurang memadai. Faktor lain adalah karena tidak ada pedoman pemeriksaan standar-profesional, di samping itu juga

${ }^{15}$ Lihat Protection of Well-Known and Famous Trademarks yang diterbilkan oleh Japanese Patent Office, Asia-Pacific Industrial Property Center, JIII. Juga bisa dilihat lebih lanjut beberapa artikel yang ditulis oleh Andre R. Bertrand, French Trademark Law: From the Well-Known Brand to the Famous Brand, EIPR, 1993 (4), h. 142.

${ }^{16}$ LihatAnnete Kurr. "Well-Known Marks, Highly Renowned Marks and Marks Having a (High) ReputationWhats It All About?" IIC. Vol. 23. No. 2 Tahun 1992, HIm. 218.

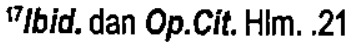


karena tidak memiliki konsep yang memadai untuk menentukan kriteria perlindungan merek terkenal;

(b) sistem pemeriksaan merek yang masih manual telah menimbulkan akibat hasil pemeriksaan yang kurang sempurna, dan hal ini menjadi salah satu alasan untuk menyimpang dari cara pemeriksaan yang profesional, cermat dan akurat;

(c) penyimpangan termasuk pula ketidakteguhan dalam menjalankan profesi sebagai kuasa hukum HaKI tejadi karena tidak ada standar, kualifikasi atau sikap profesional karena persyaratan untuk menjalankan profesi itu tidak diatur. Padahal, untuk menghadapi era globalisasi dan berkompetisi dengan kuasa hukum serupa dari luar negeri dibutuhkan persyaratan yang memadai, termasuk standar, kualifikasi dan profesionalisme. Untuk memperbaiki sistem HaKI (tidak hanya sistem hukum saja) tidak cukup pembenahan ke dalam saja tetapi juga perlu pembenahan keluar. Pelatihan untuk membentuk standar profesi termasuk pula kode etik profesi harus ditegakkan.

(d) Di samping hal-hal di atas, ada beberapa sebab lain mengapa pemilik merek terkenal mengalami kekalahan di pengadilan, yaitu: 1) kekeliruan dalam menyusun gugatan karena rasa percaya diri yang berlebihan dalam mewakili pemilik merek terkenal asing, sedangkan pihak tergugat mampu memberikan jawaban yang baik dan meyakinkan hakim, sehingga gugatan itu ditolak atau tidak diterima; 2) penyusunan gugatan dilakukan dengan baik dan benar, dan jawaban juga disusun dengan tepat dan benar namun hakim tidak memahami perkara atau sistem hukum merek sehingga gugatan itu pun gagal;

Dengan memperhatikan hal-hal tersebut di atas, sesungguhnya perlindungan merek terkenal di Indonesia bukanlah masalah hukum karena ditinjau dari segi hukum ketentuan yang memberikan perlindungan terhadap merek terkenal telah cukup memadai diatur dalam UU Merek No. 14 Tahun 1997. Persoalan utama adalah bagaimana melakukan pembenahan terhadap sumber daya manusianya yang mencakup pula etika profesi tidak hanya di dalam Kantor Merek saja tetapi juga diluar yaitu para pengusaha dan para kuasa hukum merek. Hubungan kemitraan antara aparat Kantor Merek dan para pengusaha, atau para praktisi hukum merek haruslah hubungan kemitraan yang profesional, sejajar yang saling menjaga nama baik, martabat bangsa dan negara, dan bukan hubungan kemitraan yang bersifat kolusi dan korupsi yang akhimya merugikan kepentingan nasional. Membangun hubungan kemitraan yang profesional itu tidak bisa lagi ditundatunda karena akan sangat merugikan semua pihak, termasuk Kantor Merek, dan profesi sebagai kuasa hukum merek. Harus ada tekad, rencana yang matang dan pelaksanaan yang efektif melalui pengawasan yang ketat serta sanksi yang tegas untuk membangun dan menegakkan sistem HaKl yang baik dan benar di masa mendatang. Hal itu bukan hanya tugas Kantor Merek, atau Ditjen HaKI saja tetapi juga para praktisi HaKI seluruhnya. 


\section{Daftar Pustaka}

Alison Firth. 1995.Trade Marks, the New Law. Jordans.

Insan Budi Maulana. 1999. Perlindungan Merek Terkenal di Indonesia dari Masa Ke Masa. Bandung.

Jurnal IIC tahun 1994 dan tahun 1995.

Protection of Well-Known and Famous Trademarks. Japanese Patent Office, Asia-Pacific Industrial Property Center, JIIl.
The Paris Convention dan TRIPS Agreement.. WIPO. Geneva 1997.

UU Merek Jepang No. 51 Tahun 1998. AIPPIJAPAN.

UU Merek Inggris 1994.

Yayasan Klinik HAKI (penyusun dan penerjemah). 1999. Kompilasi Undang-Undang Hak Cipta, Paten, Merek dan Terjemahan Konvensi-konvensi Di Bidang Hak atas Kekayaan Intelektual. Seri A dan Seri B. Bandung. 